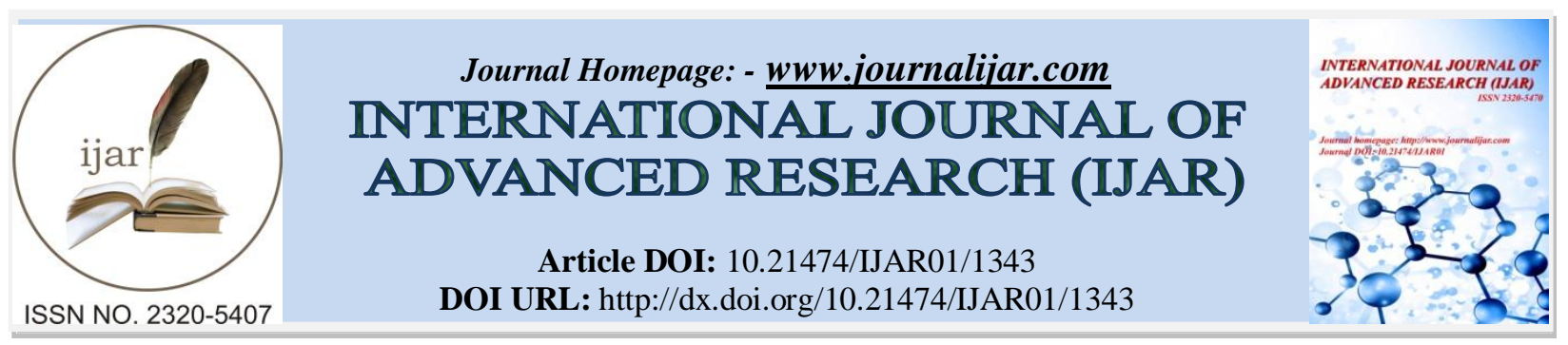

RESEARCH ARTICLE

\title{
ANTI-HYPERGLYCEMIC AND IN-VITRO ANTIOXIDANT EFFECT OF KIGELIA PINNATA FRUIT.
}

\section{"Daksh Bhatia ${ }^{1}$, Sarvesh Kumar Paliwal ${ }^{2}$, Anuj Pathak ${ }^{1}$ and Abhay Bhardwaj ${ }^{1}$.}

1. Department of Pharmacognosy, KIET School of Pharmacy, Ghaziabad - 201206, India.

2. Head, Department of Pharmacy, Banasthali University, P.O. Banasthali Vidyapith, Distt. Tonk, Rajasthan304022, India.

\section{Manuscript Info}

Manuscript History

Received: 18 June 2016

Final Accepted: 29 July 2016

Published: August 2016

Key words:-

Antioxidant, Diabetes, Oxidative stress,

Anti-hyperglycemic, Kigelia pinnata.

\section{Abstract}

Diabetes mellitus (DM) is a complex metabolic disease characterized by chronic hyperglycaemia commonly associated with oxidative stress. The present study aims at evaluating the antioxidant and antihyperglycemic potential of various concentrations of hydroalcoholic extract of Kigelia pinnata fruit. The in-vitro antioxidant activity was assessed using 1,1-Diphenyl-2-picrilhydrazyl (DPPH), nitric oxide, hydroxyl ion and hydrogen peroxide for free radical scavenging properties of the extracts, and determining their phenol and flavanoid contents. The antidiabetic activity was tested in rats following streptozocin induced hyperglycemia. The in-vitro antioxidant activity using DPPH, nitric oxide radical, hydroxyl radical and $\mathrm{H}_{2} \mathrm{O}_{2}$ radical showed $\mathrm{IC}_{50}$ value $77.49 \pm 0.38,91.07 \pm 0.62,118.91 \pm 0.43$ and $86.46 \pm 0.52 \mu \mathrm{g} / \mathrm{ml}$ respectively. The hydroalcoholic extract of the fruits with dose 250, 500 and $750 \mathrm{mg} / \mathrm{Kg}$ exhibited anti-hyperglycemic activities with $37.08 \%, 55.08 \%$ and $56.19 \%$ reduction, respectively. These findings suggest that $K$. pinnata fruits possess slight antidiabetic and good antioxidant properties, and therefore could be used as starting point for the development of herbal medicines and/or source of new drug molecules against oxidative stress or it associated disorders.

Copy Right, IJAR, 2016,. All rights reserved.

\section{Introduction:-}

Diabetes mellitus is a complex metabolic disorder characterized as state in which homeostasis of carbohydrate and lipid metabolism is improperly regulated. Type 2 diabetes accounts for $90-95 \%$ of all cases of diabetes. The main pathophysiological defect of type 2 diabetes is insulin resistance, a decrease in cellular response to insulin. Type- 2 diabetes is manifested when pancreatic beta cells fail to compensate for chronic elevated blood glucose due to dysregulation of insulin-stimulated glucose uptake in the peripheral tissues (Taheri et al., 2012;Valiathan et al., 1998).

The impaired metabolism is often accompanied with excessive release of free radicals through lipid peroxidation, due to alteration of the activity of several proteins (Collier et al., 1990), aggravated by a drastic drop in antioxidant immune mechanisms (Braynes, 1991). This imbalance generally lead to oxidative stress which is the main factor associated with the severity and death in diabetes. Diabetes mellitus is a major cause of disability, figuring among the top ten killers worldwide (Dieye et al. ,2008).Conflicting results have been reported for the role of oxidative stress in diabetes. F2-isoprostanes are prostaglandin like compounds formed in-vivo from free radical catalyzed peroxidation of arachidonic acid and have emerged as novel and direct measures of oxidative stress. F2-isoprostane 
levels have been reported to be increased in the plasma of type 2 diabetes mellitus and in the urine of type 2 and type 1 diabetic subjects (Gopaul et al., 1995; Davy et al., 1999). A correlation between impaired glycemic control and enhanced lipid peroxidation has been reported. However, lack of correlation between glycemic control and levels of 8-iso-PGF2a or MDA has been shown in another a study (Vessby et al., 2002). It was shown that oxidative stress exists in diabetic patients as evidenced by increased total antioxidant capacity in saliva and blood of patients (Astaneie et al., 2005). Oxidative stress is increased in diabetes because of multiple factors. Dominant among these factors is glucose autoxidation leading to the production of free radicals. Other factors include cellular oxidation/reduction imbalances and reduction in antioxidant defenses (including decreased cellular antioxidant levels and a reduction in the activity of enzymes that dispose of free radicals). In addition, levels of some prooxidants such as ferritin and homocysteine are elevated in diabetes. Another important factor is the interaction of advanced glycation end products (AGEs) with specific cellular receptors called AGE receptors (RAGE). Elevated levels of AGE are formed under hyperglycemic conditions. Their formation is initiated when glucose interacts with specific amino acids on proteins forming a compound that then undergoes further chemical reactions. Glycation of protein alters protein and cellular function, and binding of AGEs to their receptors can lead to modification in cell signaling and further production of free radicals (Penckofer et al., 2002).

Kigelia pinnata (KP) (Syn. Kigelia africana Benth.) (Family: Bignoniaceae) is an African tree, known as 'sausage tree', which is widely grown in the tropics and cultivated in many parts of India as an ornamental and roadside tree. In folklore medicine different parts of this plant are used in the treatment of various ailments. Dried powdered fruit is used as purgative, for the treatment of ulcers and to increase the flow of milk in lactating women (Vessby et al., 2002), whereas fruit infusion is taken as remedy for rheumatism, back pain and skin cancer. Fruit paste is used for the treatment of leprosy (Astaneie et al., 2005). In southern Africa the bark is used to treat ulcers, pneumonia, toothache (Penckofer et al., 2002) and as a remedy for syphilis and gonorrhea (Oliver-Bever, 1986). Various pharmacological studies have shown anti-implantation (Lal and Yadav, 1983), molluscicidal (Houghton, 2002), antimicrobial (Watt and Breyer, 1962), cytotoxic (Prakash, 1985), antibacterial (Kela et al., 1989) and antifungal (Akunyilli et al., 1991) activities in K. pinnata. Previous phytochemical investigations revealed isolation of iridoids (Houghton et al., 1994; Jackson et al., 2000), coumarins (Houghton, 1993), flavonoids (Gouda et al., 2003) and naphthoquinones (Govindachari et al., 1971; El-Sayyad, 1982) from this plant. Till date, no pharmacological data is available for antidiabetic activity of fruits. Hence, it would be worth studying the antidiabetic potential of $K$. pinnata.

In this work the effect of its aqueous-alcoholic extract on the blood glucose lowering effect of streptozocin induced diabetic rats has been investigated, which is one of the main parameter for checking the potential of drug in the management of Diabetes mellitus. Furthermore antioxidant potential of the plant extract has also been assessed by various in-vitro models.

\section{Material and methods :- \\ Plant collection and extraction:-}

The dried fruits of KP were purchased from the local market of Delhi and authenticated by 'Dr. H.B.Singh, Head, Raw Material, Herbarium and Museum', NISCAIR, New Delhi, and sample was submitted in the museum. Shade dried seeds were defatted with petroleum ether and then extracted with 1:1 mixture of distilled water and ethanol using triple maceration process. The crude extract was evaporated at reduced pressure in rotary film evaporator and dried further in vaccume dessicator with phosphorus pentaoxide (named KPE). The dose of $250 \mathrm{mg} / \mathrm{kg}, 500 \mathrm{mg} / \mathrm{kg}$ and $750 \mathrm{mg} / \mathrm{kg}$ were selected with reference to previous literature. The extract was suspended in 5\% Tween 80 solution for oral administration.(Kasiviswanath et al., 2005)

\footnotetext{
Animals:-

The animals were kindly provided by the Animal House of the KIET School of Pharmacy, Ghaziabad, India. Adult albino rats of either sex weighing 150-200 gm were used for the study. They were housed in polypropylene cages, per cage, with free excess to standard laboratory diet and water. The rats were maintained under standard laboratory condition at $25 \pm 2{ }^{\circ} \mathrm{C}$, relative humidity $50 \pm 15 \%$ and normal photo period $(12 \mathrm{~h}$ dark/12h light) were used for experiment. The entire experimental protocol was approved by the institutional animal ethics committee, KIET School of Pharmacy, Ghaziabad, India.

Phytochemical screening:-
} 
The alcoholic extracts obtained were subjected to preliminary phytochemical screening, to identify the chemical constituents. The methods of analysis employed were those described earlier.(Harbone and baxter, 1993; Trease and Evans, 1989).

\section{Oral glucose tolerance test (OGTT):-}

Rats were fasted overnight and divided into three groups with 6 animals in each group. Group-I received distilled water, to serve as control. Group-II animals were treated with glibenclamide $(5 \mathrm{mg} / \mathrm{kg}$, per os) to serve as a standard. Group-III animals were treated with plant extract $(500 \mathrm{mg} / \mathrm{kg})$. The control, standard and test groups were treated with drugs 30 minutes prior to a glucose load (2.5 g/kg, per os). Blood samples were collected at 15, 30, 45, 60, 75, 90 and 120 minutes after glucose loading. Serum was then separated and glucose levels measured immediately (Kumar et al., 2010).

\section{Induction of experimental diabetes:-}

The animals were allowed to fast for $18 \mathrm{hr}$ and a freshly prepared solution of streptozotocin (STZ)(55 mg/kg, i.p.) in $0.1 \mathrm{M}$ citrate buffer, $\mathrm{pH} 4.5$ was injected in volume of $1 \mathrm{ml} / \mathrm{kg}$ body wt (Chakraborty and Das, 2010). After $48 \mathrm{hr}$ of STZ administration, rats with moderate diabetes having glycosouria and hyperglycemia (i.e., with blood glucose of greater than $200 \mathrm{mg} / \mathrm{dl}$ ) were used for the experiment.

\section{Experimental design:-}

In the experiment, a total of 36 rats (30 diabetic surviving rats, 6 normal rats) were used. The rats were divided in to 6 groups of 6 rats each. Group I untreated rats receiving vehicle (5\% tween 80 in distilled water) designated as control. Group II with STZ treatment alone was considered as diabetic control. Group III, IV and V with diabetic rats, were dedicated to plant extract dose of 250,500 and $750 \mathrm{mg} / \mathrm{kg}$ body wt respectively. Group VI receiving glibenclamide $(5 \mathrm{mg} / \mathrm{kg}$ body wt, p.o.) was designated as standard. The rats received due course of doses once a day for seven days. The fasting blood glucose was taken for all rats once daily in the morning hours.

\section{Determination of blood glucose level:-}

The estimation of blood glucose level was done by using one touch glucometer (Accu check sensor) for which a drop of blood was taken from the tail vein.

\section{Estimation of total flavanoids and Phenols:-}

Aluminum chloride colorimetric method was used for flavonoids determination (Chang et al., 2002). Each plant extracts $(0.5 \mathrm{ml}$ of $1: 10 \mathrm{~g} \mathrm{ml}-1)$ in methanol were separately mixed with $1.5 \mathrm{ml}$ of methanol, $0.1 \mathrm{ml}$ of $10 \%$ aluminum chloride, $0.1 \mathrm{ml}$ of $1 \mathrm{M}$ potassium acetate and $2.8 \mathrm{ml}$ of distilled water. It remained at room temperature for $30 \mathrm{~min}$; the absorbance of the reaction mixture was measured at $415 \mathrm{~nm}$ with a double beam Shimadzu UV/Visible spectrophotometer (Japan). The calibration curve was prepared by preparing quercetin solutions at concentrations 12.5 to $100 \mathrm{~g} \mathrm{ml}^{-1}$ in methanol.

Total phenols were determined by Folin Ciocalteu reagent (McDonald et al., 2001). A dilute extract of each plant extract $(0.5 \mathrm{ml}$ of $1: 10 \mathrm{~g} \mathrm{ml}-1)$ or gallic acid (standard phenolic compound) was mixed with Folin Ciocalteu reagent ( $5 \mathrm{ml}, 1: 10$ diluted with distilled water) and aqueous $\mathrm{Na}_{2} \mathrm{CO}_{3}(4 \mathrm{ml}, 1 \mathrm{M})$. The mixtures were allowed to stand for 15 min and the total phenols were determined by colorimetry at $765 \mathrm{~nm}$. The standard curve was prepared using 0,50 , 100, 150, 200, $250 \mathrm{mg} \mathrm{L-1}$ solutions of gallic acid in methanol:water (50:50, v/v). Total phenol values are expressed in terms of gallic acid equivalent ( $\mathrm{mg} \mathrm{g}-1$ of dry mass), which is a common reference compound.

\section{DPPH radical scavenging assay:-}

The stable 1,1-diphenyl-2-picryl hydrazyl radical (DPPH) was used for determination of free radical-scavenging activity of the extracts (Teugwa et al., 2013). Different concentrations of each extract were prepared in distilled water, $30 \mu \mathrm{L}$ of each solution mixed with $1 \mathrm{~mL}$ of ethanol solution of DPPH $(0.1 \mathrm{mM})$ and incubated for $30 \mathrm{~min}$ in the dark. BHA was used as standard for this assay. At the end of this period, the absorbance was recorded at $517 \mathrm{~nm}$ using a spectrophotometer, and the antiradical activity of each concentration calculated as percentage reduction of DPPH concentration, with reference to the optical density at the start, as followed: $\%$ scavenged $[$ Free radicals $]=[($ Ao - A 1$) /$ Ao $] \times 100$ where

Ao was the absorbance of the control and A1 was the absorbance in the presence of the sample of extract or standard. 


\section{Nitric oxide radical scavenging activity:-}

Nitric oxide scavenging activity was measured spectrophotometrically (Govindrajan et al., 2003). Extract, prepared in ethanol, was added to different test-tubes in varying concentrations. Sodium nitroprusside $(5 \mathrm{mM})$ in phosphate buffer was added to each test tube to make volume up to $1.5 \mathrm{ml}$. Solutions were incubated at $25^{\circ} \mathrm{C}$ for 30 minutes. Thereafter, $1.5 \mathrm{ml}$ of Griess reagent (1\% sulphanilamide, $0.1 \%$ naphthylethylenediamine dichloride and $3 \%$ phosphoric acid) was added to each test tube. The absorbance was measured, immediately, at $546 \mathrm{~nm}$ and percentage of scavenging activity was measured with reference to ascorbic acid as standard.

\section{Inhibition of hydroxyl radical:-}

Hydroxyl radical scavenging activity of seed extract was assayed by the established method (Smirnoff and Cumbes, 1989). The reaction mixture $3.0 \mathrm{ml}$ contained $1.0 \mathrm{ml}$ of $1.5 \mathrm{mM} \mathrm{FeSO}, 0.7 \mathrm{ml}$ of $6 \mathrm{mM}$ hydrogen peroxide, $0.3 \mathrm{ml}$ of $20 \mathrm{mM}$ sodium salicylate and varied concentrations of the extracts. After incubation for 1 hour at $37^{\circ} \mathrm{C}$, the absorbance of the hydroxylated salicylate complex was measured at $562 \mathrm{~nm}$. The scavenging activity of hydroxyl radical effect was calculated as follows:

[1-(A1-A2) / A0] x 100, where A0 is absorbance of the control (without extract) and A1 is the absorbance in the presence of the extract, $\mathrm{A} 2$ is the absorbance without sodium salicylate.

\section{Hydrogen peroxide scavenging activity:-}

The ability of extract to quench hydrogen peroxide $\left(\mathrm{H}_{2} \mathrm{O}_{2}\right)$ was determined spectrophotometrically. Different concentrations of extract or ascorbic acid were dissolved in $3.4 \mathrm{~mL}$ of $0.1 \mathrm{M}(\mathrm{pH} 7.4)$ of phosphate buffer solution and mixed with $0.6 \mathrm{~mL}$ of $40 \mathrm{mM}$ solution of $\mathrm{H}_{2} \mathrm{O}_{2}$. Absorbance of $\mathrm{H}_{2} \mathrm{O}_{2}$ at $230 \mathrm{~nm}$ was determined 10 minutes later in a spectrophotometer. For each concentration, a separated blank sample was used for background subtraction (Kaithwas et al., 2014).

\section{Reductive ability:-}

Various concentrations of extract of $(1 \mathrm{ml})$ were mixed with $2.5 \mathrm{ml}$ of $1 \%$ sodium phosphate buffer $(\mathrm{pH} 6.6)$ and 2.5 $\mathrm{ml}$ of $1 \%$ potassium ferricyanide. Then the mixture was incubated at $50^{\circ} \mathrm{C}$ for $30 \mathrm{~min}$. After $2.5 \mathrm{ml}$ of $10 \%$ TCA were added to the mixture was centrifuged at $3,000 \mathrm{rpm}$ for $10 \mathrm{~min}$. The upper layer $(2.5 \mathrm{ml})$ was mixed with $2.5 \mathrm{ml}$ deionized water with $0.5 \mathrm{ml}$ of $0.1 \%$ of ferric chloride and the absorbance was measured at $700 \mathrm{~nm}$ (Jie Yin et al., 2008).

\section{Statistical analysis:-}

Results were expressed as mean \pm S.E.M. Data were statistically analyzed by one-way ANOVA, followed by Tukey's multiple comparison test, with the level of significance set at $\mathrm{P}<0.05, \mathrm{P}<0.01$ and $\mathrm{P}<0.001$.

\section{Results and Discussion:-}

Phytochemical profile:-

The defatted hydroalcoholic extract of the plant material yield (16.17\%). The phytochemical analysis of the extract revealed the presence of a diversity of chemical families, including flavonoids, sterols, tannins, glycosides, alkaloids, fixed oils and polyphenols. However, lipids were very less in the extract.

\section{Effect of Kigelia pinnata on serum glucose in normal fasted rats:-}

In the control groups a significant increase in blood glucose levels was noticed up to 90 minutes which was followed by a reduction after 90 minutes to 120 minutes (Table 1). Treatment with the standard drug glibenclamide (groupII), blood glucose rose at 30 minutes followed by subsequent fall up to 120 minutes. It was observed from the present study that the administration of KPE increased the glucose levels up to 60 minutes. A significant reduction in the blood sugar level was observed in the tested groups when compared with control group.

\section{Hypoglycemic effect:-}

The management of diabetes is more concerning inspite of its treatment. Many synthetic drugs are in the flow for its management but due to side effects, attention toward herbal treatment is increasing day by day. The effects of extract of fruit were studied on rats for antidiabetic effect. The doses used were 250,500 and $750 \mathrm{mg} / \mathrm{kg}$ body wt. All the doses were showed marked decrease in the blood glucose level during the study of one week. The standard drug used for the comparison was glibenclamide which showed 59.58\% decrease in the blood glucose level. $250 \mathrm{mg}$ dose showed $37.08 \%$ decrease, $500 \mathrm{mg}$ dose showed $55.08 \%$ and $750 \mathrm{mg}$ dose showed $56.19 \%$ decrease in the 
blood glucose level within one week and there comparisons are presented graphically (Figure 1). In Diabetic controlled group rats there was no significant decrease in the blood glucose level.

Simultaneously general behavior of the animals were also recorded during the study and it was found that complications during diabetes like thirst, fatigue, irritation etc. were very less in the animals feed with herbal drug in comparison to diabetic controlled rats and rats which received glibenclamide.

\section{Total phenolic and flavonoid content:-}

Phenolic compounds are secondary plant metabolites, which contribute to the overall antioxidant activities of plants mainly due to their redox properties.

The total phenolic content of KP extract was determined by Folin-Ciocalteu assay using gallic acid as a standard phenolic compound. The extract had the phenolic content (312.8 $\pm 25.2 \mathrm{mg} \mathrm{GAE} \mathrm{g-1),} \mathrm{which} \mathrm{may} \mathrm{have} \mathrm{contributed}$ towards its radical scavenging activity in both DPPH and nitrc oxide radical scavenging assay.

The content of total flavanoids was also measured spectrophotometrically by using the aluminium chloride colorimetric assay. The flavonoid content of KP was expressed as quercetin equivalents in $\mathrm{mg} / \mathrm{g}$ dry weight (36.8 $\pm 3.2 \mathrm{mg} / \mathrm{g}$ dry weight) and a calibration curve of quercetin was used.

\section{DPPH radical scavenging activity:-}

In the DPPH test, the stable, nitrogen centered, coloured, DPPH free radical is reduced either by hydrogen donor or antioxidant to a non-radical DPPH-H and the decrease in colour of DPPH radical is monitored over a time period (Singleton and Rossi, 1965). The extract showed a sharp drop in DPPH colour intensity, indicating high antioxidant activity in quenching DPPH radicals. The DPPH radical scavenging potential of various concentrations of extracts and BHA are presented in Figure. 2 The synthetic antioxidant showed highest DPPH radical scavenging activity among the tested samples with an $\mathrm{IC}_{50}$ value of $8.1 \pm 0.26 \mu \mathrm{g} / \mathrm{ml}$. The $\mathrm{IC}_{50}$ value of the plant extract was found to be $77.49 \pm 0.38 \mu \mathrm{g} / \mathrm{ml}$.

Nitric oxide radical scavenging activity:-

Extracts of KP revealed the significant presence of antioxidative agents like flavonoids and polyphenols. Nitric Oxide (NO) scavenging assay is based on the scavenging ability of the extracts as well as ascorbic acid, which is used as standard. The scavenging of $\mathrm{NO}$ was found to increase in dose dependent manner. At the maximum concentration, inhibition was found to be $85.66 \%$ for ascorbic acid, which serves as the standard. For plant extract, inhibition was found to be $73.16 \%$ (Figure 2) and the $\mathrm{IC}_{50}$ value $91.07 \pm 0.62 \mu \mathrm{g} / \mathrm{ml}$.

\section{Inhibition of hydroxyl radical:-}

The hydroxyl radical is the most reactive of the reactive oxygen species, and it induces severe damage in adjacent biomolecules (Gutteridge, 1984). The hydroxyl radical can cause oxidative damage to DNA, lipids and proteins (Spencer, 1994). The hydroxyl radical scavenging activity of KP extract was assessed by its ability to compete with salicylic acid for hydroxyl radicals in the hydroxyl generating/detecting system. In the present study, the hydroxyl radical-scavenging effect of the KP extract at maximum concentration was found to be $63.44 \%$ (Figure 2). The $\mathrm{IC}_{50}$ value was found to be $118.91 \pm 0.43 \mu \mathrm{g} / \mathrm{ml}$. Hence, the KP extract can be considered as a good scavenger of hydrox yl radicals.

\section{Hydrogen peroxide scavenging activity:-}

Scavenging activity of hydrogen peroxide in KPE $(100 \mu \mathrm{g})$ and BHT $(50 \mu \mathrm{g})$ as reference compound was equal and shown to be $72 \%$ at initial time respectively (Figure 2). The composition of hydrogen peroxide into water may occur according to the antioxidant compounds as the antioxidant component present in the extract is good electron donors, they may accelerate the conversion of $\mathrm{H}_{2} \mathrm{O}_{2}$ to $\mathrm{H}_{2} \mathrm{O}$. The $\mathrm{IC}_{50}$ value was found to be $86.46 \pm 0.52 \mu \mathrm{g} / \mathrm{ml}$.

\section{Reductive ability:-}

The reducing power of a compound is associated with electron donating capacity and serves as an indicator of antioxidant activity (Siddhuraju et al., 2002; Yen et al., 1993). The ability of KP extracts to reduce ferric to ferrous was determined and compared with that of a standard BHA and ascorbic acid. At all concentrations extract exhibited lower activity than the standards. (Table 2) . 
Diabetes is a prevalent systemic disease affecting a significant proportion of the population worldwide. The effects of diabetes are devastating and well documented. There is increasing evidence that in certain pathologic states, especially chronic diseases, the increased production and/or ineffective scavenging of reactive oxygen species (ROS) may play a critical role. High reactivity of ROS determines chemical changes in virtually all cellular components, leading to lipid peroxidation. Production of ROS and disturbed capacity of antioxidant defense in diabetic subjects have been reported. It has been suggested that enhanced production of free radicals and oxidative stress is central event to the development of diabetic complications. This suggestion has been supported by demonstration of increased levels of indicators of oxidative stress in diabetic individuals suffering from complications. Therefore, it seems reasonable that antioxidants can play an important role in the improvement of diabetes. There are many reports on effects of antioxidants in the management of diabetes.

The effect of K.pinnata was studied for the management of diabetes mellitus. Streptozotocin has been observed to cause a massive destrution of the $\beta$ - cell of the islets of langerhans and induce hyperglycemia. The perusal of literature shows that studies were carried out on this plant with regard and has some scientific evidence for antidiabetic activity but on various other parts. The plant is credited with flavones glycosides, which in general believed to be responsible for antidiabetic activity. The possible mechanism by which K.pinnata brings about its hypoglycemic action may be potentiating the insulin effect of plasma by increasing either the pancreatic secreation of the insulin from the $\beta$-cell of islets of langerhans or its release from bound insulin.

DPPH is a relatively stable free radical and the assay determines the ability of KPE to reduce the radical to the corresponding hydrazine by converting the unpaired electrons to paired ones, which infect is the action of the antioxidants. The dose dependent inhibition of DPPH radical (Fig 2) indicates that KPE causes reduction of DPPH radical in a stoichometric manner (Sanchez Moreno, 2002).

Nitric oxide (NO) is an important chemical mediator generated by endothelial cells, macrophages, neurons etc and is involved in the regulation of various physiological processes. Excess concentration of NO is associated with several diseases. Oxygen reacts with the excess nitric oxide to generate nitrite and peroxy nitrite anions, which act as free radicals (Sainani et al., 1997).In the present study the extract competes with oxygen to react with nitric oxide and thus inhibits the generation of the anions.

A substance may act as an antioxidant due to its ability to reduce ROS by donating hydrogen atom. The reducing property of KPE (Table 2) implies that it is capable of donating hydrogen atom in a dose dependent manner. The high content of phenolic compounds in the extract may be a contributing factor towards antioxidant activity because the phenolic compounds are known to have direct antioxidant property due to the presence of hydroxyl groups, which can function as hydrogen donor.

Preliminary phytochemical analysis shows the presence of polyphenols and flavonoids in KPE which are well known. Thus the antioxidant potential of Kigelia pinnata extract could be attributed due to the presence of polyphenolic compounds.

Table 1:- Effect of KP Extract on Serum Glucose in Normal Fasted Rats

\begin{tabular}{|l|l|l|l|l|l|l|}
\hline \multirow{3}{*}{ Group } & \multirow{2}{*}{ Treatment } & \multicolumn{5}{l|}{ Serum Glucose $(\mathrm{mg} / \mathrm{dl})$ (Mean \pm SD) } \\
\cline { 3 - 7 } & & Time after glucose administration (in minutes) & \multicolumn{3}{l|}{} \\
\cline { 3 - 7 } & & 0 & 30 & 60 & 90 & 120 \\
\hline I & Control & $75.52 \pm 4.31$ & $89.01 \pm 8.52$ & $125.82 \pm 7.33$ & $149.12 \pm 6.41$ & $114.38 \pm 5.25$ \\
\hline II & Standard & $73.14 \pm 5.46$ & $86.12 \pm 4.34$ & $97.44 \pm 5.27$ & $84.38 \pm 5.14$ & $78.83 \pm 5.37$ \\
\hline III & KPE & $78.43 \pm 5.42$ & $92.36 \pm 5.32$ & $119.36 \pm 9.64$ & $100.38 \pm 6.22$ & $96.28 \pm 5.88$ \\
\hline
\end{tabular}

Values are means \pm S.E.M.

$\mathrm{P}<0.05$ as compared with control are considered significant 
Table 2:- Reducing Ability of KP Extract

\begin{tabular}{|l|l|l|l|}
\hline \multirow{2}{*}{$\begin{array}{l}\text { Concentration } \\
\mu \mathrm{g} / \mathrm{ml})\end{array}$} & Absorbance at 700 $\mathrm{nm}$ & BHA & KPE \\
\cline { 2 - 4 } & Ascorbic acid & $0.241 \pm 0.034$ & $0.031 \pm 0.009$ \\
\hline 50 & $0.386 \pm 0.039$ & $0.383 \pm 0.029$ & $0.092 \pm 0.038$ \\
\hline 100 & $0.438 \pm 0.024$ & $0.490 \pm 0.037$ & $0.301 \pm 0.023$ \\
\hline 150 & $0.521 \pm 0.042$ & $0.583 \pm 0.023$ & $0.384 \pm 0.067$ \\
\hline 200 & $0.741 \pm 0.039$ & $0.645 \pm 0.056$ & $0.512 \pm 0.051$ \\
\hline 250 & $0.834 \pm 0.052$ & $0.754 \pm 0.058$ & $0.593 \pm 0.067$ \\
\hline 300 & $0.934 \pm 0.063$ & & \\
\hline
\end{tabular}

Values are mean \pm SEM of 3 replicates

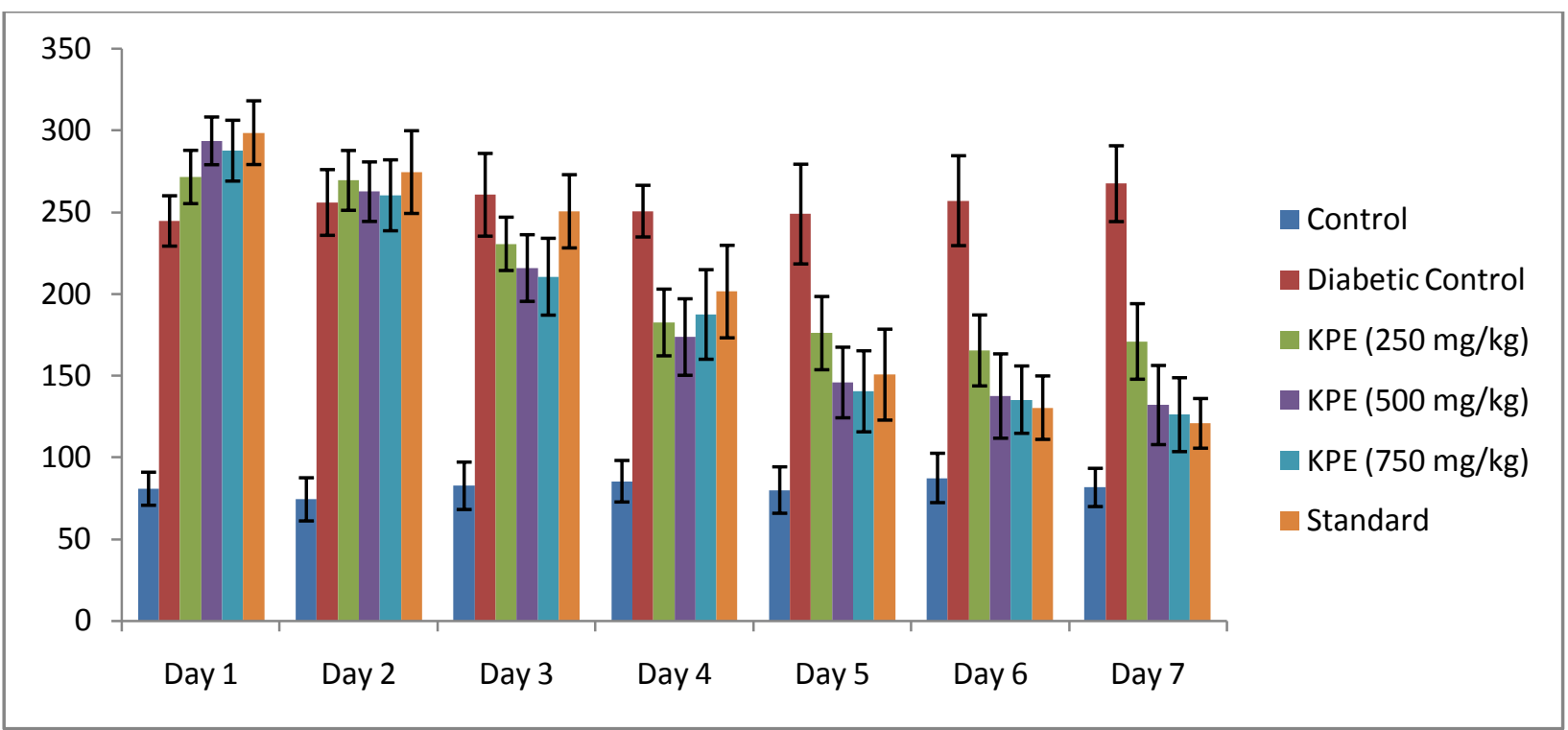

Figure 1:- Effect of KPE on Serum Blood Glucose Level in STZ Induced Diabetic Rats For 7 Days.

Values are means \pm S.E.M.

$\mathrm{P}<0.001$ as compared with control are considered significant

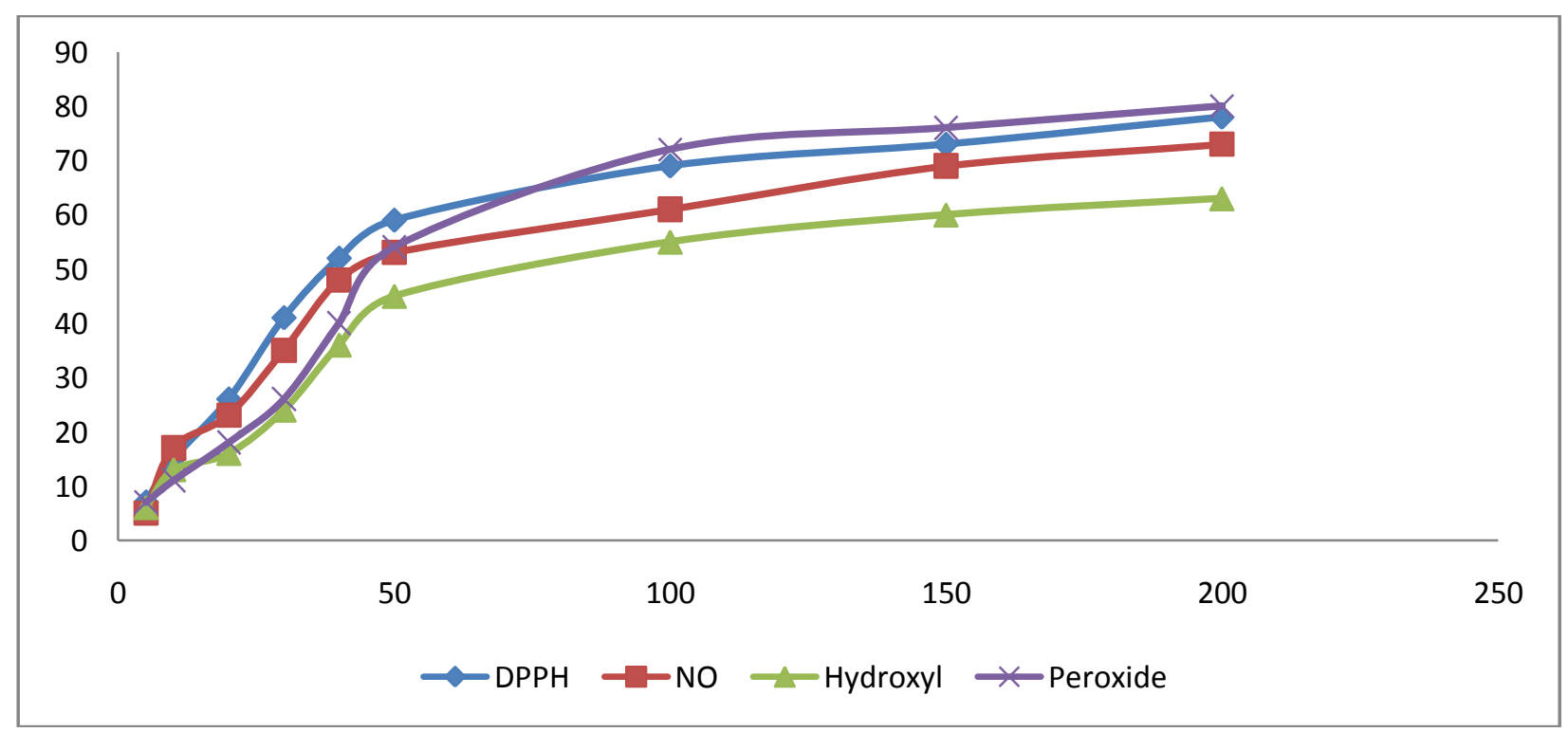

Figure 2 :- Effect of KPE on Various In-Vitro Free Radical Models. 


\section{References:-}

1. Akunyili, D.N., Houghtan, P.J. (1993): Meroterpenoids and napthaquinones from Kigelia pinnata. Phytochem., 32:1015-8.

2. Akunyilli, D.N., Houghton, P.J., Roman, A. (1991): Antimicrobial activities of the stembark of Kigelia pinnata. J Ethnopharmacol., 35:173.

3. Astaneie, F., Afshari, M., Mojtahedi, A., et al. (2005): Total antioxidant capacity and levels of epidermal growth factor and nitric oxide in blood and saliva of insulin-dependent diabetic patients. Arch. Med. Res., 36(4):376-81.

4. Braynes, J.W. (1991): Role of oxidative stress in development of complications in diabetes. Diabetes, 40:405412.

5. Chakraborty, U. and Das, H. (2010): Antidiabetic and antioxidant activities of Cinnamomum tamala leaf extracts in STZ-treated diabetic rats. Global J. Biotech. Biochem., 5(1) :12-18.

6. Chang, C., Yang, M., Wen, H. and Chern, J. (2002): Estimation of total flavonoid content in propolis by two complementary colorimetric methods. J. Food Drug Anal., 10: 178-182

7. Collier, A., Wilson, R., Bradley, H., Thomson, J.A. and Small, M. (1990): Free radical activity in type 2 diabetes. Diab. Med., 7:27-30.

8. Davy, G., Ciabattoni, G., Consoli, A., Mezzetti, A., Falco, A., Santarone, S., et al. (1999): In vivo formation of 8-iso-prostaglandin F2a and platelet activation in diabetes mellitus: effects of improved metabolic control and vitamin E supplementation. Circulation, 99:224-9.

9. Dieye, A.M., Sarr, A., Diop, S.N., N'Diaye, M., Sy, G.Y., Diarra, M., Gaffary, L.R., Sy, A.N. and Faye, B. (2008): Medicinal plants and the treatment of diabetes in Senegal: Survey with patients. Fund. Clin. Pharmacol., 22:211-216.

10. El-Sayyad, S.M. (1982): Flavonoids of the leaves and fruits of Kigelia pinnata. Fitoterapia, 52:189-91.

11. Gopaul, N.K., Anggard, E.E., Mallet, A.I., Betteridge, D.J., Wolff, S.P., et al. (1995): Plasma 8-epi-PGF2 alpha levels are elevated in individuals with NIDDM. FEBS Letters, 368:225-9.

12. Gouda, Y.G., Abdel-Bakey, A.M., Darwish, F.M., Mohamed, K.M., Kasai, R., Yamasaki, K. (2003): Iridoids from Kigelia pinnata DC. fruits. Phytochem., 63:887-92.

13. Govindachari, T.R., Patankar, S.J., Viswanathan, N. (1971): Isolation and structure of two new dihydroisocoumarins from Kigelia pinnata. Phytochem., 10:1603-6.

14. Govindarajan, R., Rastogi, S., Vijayakumar,M et al (2003): Studies on antioxidant activities of Desmodium gangeticum. Biol. Pharma. Bull., 26:1424.

15. Gutteridge, M.C. (1984): Reactivity of hydroxyl and hydroxyl-like radicals discriminated by release of thiobarbituric acid reactive material from deoxy sugars, nucleosides and benzoate. The Biochem. J., 224: 761-767.

16. Harbone, J.B., Baxter, H.H. (1993): Phytochemical Dictionary: A hand Book of Bioactive Compound from plants. Washington, D.C: Taylor and Francis, p. 237.

17. Houghton, P.J. (2002): The sausage tree (Kigelia africana): ethnobotany and recent scientific work. S. Afr. J. Bot., 68:14-20.

18. Houghton, P.J., Akunyili, D.N. (1993): Iridoids from Kigelia pinnata bark. Fitoterapia, 64:473-4.

19. Houghton, P.J., Photiou, A., Uddin, S., Shah, P., Browning, M., Jackson, S.J., Retsas, S. (1994): Activity of extracts of Kigelia pinnata against melanoma and renal carcinoma cell lines. Planta Med., 60:430-3.

20. Inoue, K., Inouye, H., Chen, C. (1981): A naphthoquinone and a lignan from the wood of Kigelia pinnata. Phytochem., 20:2271-6.

21. Jackson, S.J., Houghton, P.J., Retsas, S., Photiou, A. (2000): In vitro cytotoxicity of norviburtinal and isopinnatal from Kigelia pinnata against cancer cell lines. Planta Med., 66:758.

22. Jie, Y., Seong, H. and Myeong-Hyeon,W. (2008): Antioxidant and antidiabetic activities of extracts from Cirsium japonicum roots. Nutr. Res. Prac., 2(4):247-251.

23. Kaithwas, G., Singh, P. and Bhatia, D. (2014): Evaluation of in vitro and in vivo antioxidant potential of polysaccharides from Aloe vera (Aloe barbadensis Miller) gel. Drug chem toxicol., Apr;37(2):135-43.

24. Kasiviswanath, R., Ramesh, A. and Kumar, K.E. (2005): Hypoglycemic and antiyperglycemic effect of Gmelina asiatica Linn in normal and in alloxan induced diabetic rats. Biol. Pharma. Bull., 28(4): 729-732.

25. Kela, S.L., Ogunsusi, R.A., Ogbogu, V.C., Nwude, N. (1989): Revue D'elevage et de Medecine Veterinaire Des Pays Tropicaux, 42: p. 20.

26. Kumar, R.P., Sujatha, D., Saleem, T.S.M., Chetty, C.M. and Ranganayakulu, D. (2010): Potential antidiabetic and antioxidant activities of Morus indica and Asystasia gangetica in alloxan induced diabetes mellitus. J. experi. Pharmacol., $2: 29-36$. 
27. Lal, S.D., Yadav, B.K. (1983): Folk medicine of Kurukshetra district (Haryana). India Econ Bot, 37:299.

28. McDonald, S., Prenzler, P.D., Autolovich, M., Robards, K. (2001): Phenolic content and antioxidant activity of olive extracts. Food Chem., 73:73-84.

29. Oliver-Bever, B. (1986): Medicinal plants in tropical West Africa. Cambridge, London, New York, New Rochelle, Sydney: Cambridge University Press, 240.

30. Penckofer, S., Schwertz, D. and Florczak, K. (2002): Oxidative stress and cardiovascular disease in type 2 diabetes: the role of antioxidants and prooxidants. The J. Cardiovas. Nurs., 16(2):68-85.

31. Prakash, A.O., Sexana, V., Shukla, S., Tewari, R.K., Mathur, S., Gupta, A., Sharma, S., Mathur, R. (1985): Anti-implantation activity of some indigenous plants in rats. Acta Eur. Fertil., 16:441-8.

32. Sainani, G.S., Manika, J.S. and Sainani, R.G. (1997): Oxidative stress: a key factor in pathogenesis of chronic diseases. Med. Update, 1: 1.

33. Sanchez Moreno, C. (2002): Methods used to evaluate the free radical scavenging activity in foods and biological systems. Food Sci. Tech. Intern., $8: 122$.

34. Siddhuraju, P., Mohan, P.S. and Becker, K. (2002): Studies on the antioxidant activity of Indian laburnum (Cassia fistula L.): a preliminary assessment of crude extracts from stem bark, leaves, flowers and fruit pulp. Food Chem., 79:61-67.

35. Singleton, V.L. and Rossi, J.A. (1965): Colorimetry of total phenolics with phosphomolybdic-phosphotungstic acid reagents. Amer. J. Enol. Viticulture, 16:144-158.

36. Smirnoff, N., Cumbes, Q.J. (1989): Hydroxyl radical scavenging activity of compatible solutes. Phytochem. 28: 1057-1060.

37. Spencer, J.P.E., Jenner, A. and Aruoma, O.I. (1994): Intense oxidative DNA damage promoted by L-DOPA and its metabolites, implications for neurodegenerative disease. FEBS Letters, 353: 246-250.

38. Taheri, E., Djalali, M., Saedisomeolia, A., Moghadam, A.M., Djazayeri, A. and Qorbani, M. (2012): The relationship between the activates of antioxidant enzymes in red blood cells and body mass index in Iranian type 2 diabetes and healthy subjects. J. Diab. Metab. Disor., 11:3.

39. Teugwa, C.M., Mejiato, P.C., Zofou, D., Tchinda, B.T. and Boyom, F.F. (2013): Antioxidant and antidiabetic profiles of two African medicinal plants: Picralima nitida (Apocynaceae) and Sonchus oleraceus (Asteraceae). BMC Comple. Altern. Med., 13:175.

40. Trease, G.E., Evans, M.C. (1989): Text book of Pharmacognosy. London: Bailiere Tindall, 13th ed.

41. Valiathan, M.S. (1998): Healing plants. Cur. Sci., 75:1122-1127.

42. Vessby, J., Basu, S., Mohsen, R., Berne, C. and Vessby, B. (2002): Oxidative stress and antioxidant status in type 1 diabetes mellitus. J Intern. Med., 251: 69-76.

43. Watt, J.M., Breyer-Brandwijk, M.G. (1962): The medicinal and poisonous plants of southern and eastern Africa. Edinburgh and London: E. and S. Livingstone Ltd., p. 142.

44. Weiss, C.R., Moideen, S.V.K., Croft, S.L., Houghtan, P.J. (2000): Activity of extracts and isolated naphthoquinones from Kigelia pinnata against Plasmodium falciparum. J. Nat. Prod., 63:1306-9.

45. Yen, G.C., Duh, P.D. and Tsai, C.L. (1993): Relationship between antioxidant activity and maturity of peanut hulls. J. Agric. Food Chem., 41:67-70. 